\title{
Morphological Structures of Historical Turkish Cities
}

\section{Mehmet Topçu*}

\begin{abstract}
In this study, morphological structures of the traditional fabrics of cities in Turkey, which have been shaped under the influence of various different cultures and geographical and climatic conditions in the historical process are presented via a mathematical interpretation. In this scope, spatial configuration and morphological structures of the historical cores of a total of fourteen cities selected from the seven geographical regions of Turkey, two cities from each (from the Marmara Region, Edirne and Bursa; from the Black Sea Region, Kastamonu and Trabzon; from the Central Anatolia Region, Sivas and Kayseri; from the Eastern Anatolia Region, Kars and Erzurum; from the Aegean Region, Muğla and Kütahya; from the South Eastern Anatolia Region, Urfa, Mardin and lastly from the Mediterranean Region, Tarsus and Antakya) region were analyzed comparatively using the Space Syntax method. In this method, the cities were analyzed in three main categories using eleven different parameters. These categories are convex space, axial space and syntactic space. Convex space analyzes were made using the paramters of convex articulation, convex deformation of the grid, grid convexity and convex ringness; axial space analyses were made using the paramters of axial articulation, axial integration of convex space, grid axiality and axial ringness; finally, syntactic space analyses were made using the parameters of integration, intelligibility and synergy. In
\end{abstract}

Keywords: urban morphology, space syntax, convex space, historical cities, Turkey

*Assoc. Prof., Faculty of Architecture and Design, Konya Technical University, Konya, Turkey. ORCID

E-mail: mehmetopcu@gmail.com 
conclusion, it could be said that historical fabrics of the cities in Turkey have synchronous structures, manifest regular reflections, have organic systems compared with the grid systems, and constitute higher intellibility and synergy.

\section{INTRODUCTION}

Hillier and Hanson describe societies as spatial formations (Hillier \& Hanson, 1984). Societies have settled in different regions on earth. People meet each other and convey information as a consequence of communication that has arisen within and between these regions. The concept that we name space, on the other hand, is an attestation of the existence of the society inhabiting that space. However, a society does more than existing in a space.

The field of urban morphology, a branch of science born in the first half of the twentieth century, investigates, through deeper analyses, processes of formation and transformation as well as characteristics of urban spaces created by societies in the course of history (Conzen, 1960; Whitehand, 1986). Urban morphology has been explored by numerous scholars in England, Italy and France, and indeed instead of being restricted to these countries, it has been further studied by many independent scholars in other countries (Moudon, 1997). The afore mentioned three countries have come up with their own approaches to urban morphology and established schools of morphology to enable furthering of these approaches. The work in England in this regard was initiated by M.R.G. Conzen and continued by Whitehand. Their endeavors were on the whole on an urban scale. In Italy, on the other hand, studies pioneered by Muratori were conducted predominantly at the building level aimed at preserving historical and architectural heritage. Work undertaken by these two schools added a new dimension to urban morphology in subsequent years, and as a result social dimension in urban morphology was investigated when architects Panerani and Castex and sociologist De Paule combined their efforts. This school, like the other two schools, was founded as a reaction to the disregard shown to history (Moudon, 1997). Urban morphology is an in determining the transformation processes of urban fabrics, making sense of the historical roots of spatial and functional structures and bringing them to the present day (Larkham, 2002). In addition, Urban morphology has become a common and important research method for the analysis of the physical structures of cities through quantitative analysis. In this context, Hillier and Hanson, (1984) with the support of technological developments, combined this morphological concept with quantitative analysis of city patterns and called it 'space syntax'. According to Hillier, 
space syntax is a method that can be used for morphological analyses of buildings, architectural plans, urban areas and urban plans. It is possible to give quantitative descriptions of built spaces by using this method (Hillier \& Hanson, 1984). At this point, the space syntax method has become an effective method in studies on urban morphology as it allows comparative analyses of obtained quantitative data and intepretation of the transformations that cities have undergone in the historical process as well as revealing the relationship between these transformations and the social structure (Kubat, 1997). The purpose of this study is to be able to understand, at a deeper level via comparative analyses, the present forms of the historical cores of the cities in Turkey, which took shape in the course of time, through the space syntax method according to their geographical distribution. In this scope, fourteen cities in Turkey were selected to be included in the sample for analysis on the basis of their geographical locations and historical processes. The geography where the greater part of Turkey is located is named Anatolia, which serves as a bridge between Asia and Europe.

\section{HISTORY OF ANATOLIA IN BRIEF}

Anatolia is rich in architecture and urban structure, reflecting its geographical location and the influence of several civilizations (Kubat, 2010).

When we take a look at the structure of Anatolia before the common era, we see that small communities that lived in caves or rock coves 12.000 years ago during the Old Neolithic Age had to adopt a sedentary life style during the Neolithic Age between the years 8.000 and 5.000 A.D. years as their food stuffs were now obtained from the soil; then, these productive communities transformed into kingdoms and cities when agriculture and animal farming developed in the Bronze Age (Kejanll, 2005).

Following these periods, migration and conquests became important factors affecting the structure of the cities in Anatolia. The Hittite State, which was established in the 16th century B.C.E, was destroyed in the 12 th century B.C.E. as a result of immigration from the Agean Sea, and subsequently Greek states emerged.

The era of Roman Empire in Anatolia began in 30 B.C.E. and was replaced by the Byzantine State, also called the Eastern Roman Empire, in 330 B.C.E. During the Roman Empire, the Anatolian cities were designated as cities that did not possess the rights enjoyed by the Roman citizens and were used as sources to obtain mercenaries (Kaya, 2003). The cities of the Byzantine State, on the other hand, were initially under the influence of this approach and 
demonstrated a physically complex and varied structure chacaterized by detachment from each other, serving military purposes and based on an agricultural lifestyle (Tanyeli, 1987). The Turks, who began to settle in Anatolia after the Battle of Manzikert, became the founders of the Anatolian Seljuk State, which reigned between 1075 and 1272 . When the urban structure of this state is examined, it is seen that the Turks reflected on the Byzantine cities they conquered the experiences they had gained during the migrations before their settlement in Anatolia. These migrations, which took place from Central Asia to Anatolia betwen the 9th and 11th centuries, had ethnic, religious, socio-cultural, military and political impacts on the Turkish society as a consequence of the influence of the Central Asian urban culture, the interactions between Iran and Islam and the Greek and Roman civilization in Anatolia (Özcan, 2006).

These influences on Anatolian cities have been, in a sense, indicators of how different communities and cultures have affected each other and how the cities have been shaped based on culture. Immigrations from the east moved further into inland and as a result cities located in these areas shrank physically and were confined within the boundaries of the city walls. Byzantine cities assumed an urban fabric dominated by Turkish populace when old cities grew and a new urban structure emerged; new cities were founded and nomadic people became urban dwellers. (Kuban, 1968).

The Ottoman Principality, which was one of the principalities scattered across Anatolia in 1300, declared its independence from the Ilkhanidsin 1299 as a consequence of policies based on diplomatic skills and aimed at improving economic potential rather than military conquests. Subsequently, making efficient use of the conflicts afflicting the Byzantine State, it brought an end to the Byzantine State by conquering Istanbul (Fierro, 2011).

At the height of its power in the 16th century, the Ottoman State secured its domination in Anatolia and the Balkans and was deemed a world power in terms of both its economy and military force. Undergoing a process of decline from that period on and failing to overcome ethnic conflicts and internal strife, the empire came to a point of disintegration as a result of the defeat it suffered in World War I. However, the War of Liberation fought in its wake led to the foundation of the Turkish Republic as a new Turkish state in Anatolia in the contemporary world. 


\section{SELECTION OF SAMPLE AREAS}

In this study, the classification of seven geographical regions (Marmara, Black Sea, Central Anatolia, East Anatolia, Aegean, Southeast Anatolia and Mediterranean) adopted by geographers was used as a criterion in the selection of the study sample to investigate the morphological structure of historical cities in Turkey (Figure 1). For instance, there are various different housing types in different regions that are totally different from one another, reflected in the way the cities were established to their urban fabric and transportation systems, because climatic conditions, natural vegetation and distribution of agricultural products are extremely varied (Aru, 1998). Two cities were chosen from each of the seven geographical regions in Turkey and thus a comparative analysis was made of the spatial setup and morphological structures of the historical cores of the fourteen cities in total. These cities reflect, in addition to their geograpical differences, traces of rich cultural transformations they have undergone in the historical process of Anatolia.

The selected cities involve Edirne and Bursa in the Marmara Region, Kastamonu and Trabzon in the Black Sea Region, Sivas and Kayseri in the Central Anatolia Region, Kars and Erzurum in the Eastern Anatolia Region, Muğla and Kütahya in the Aegean Region, Urfa and Mardin in the South Eastern Anatolia Region and finally Tarsus and Antakya in the Mediterranean Region (Figure 1). The boundaries determined in a study conducted by Aru (Aru, 1998) on Turkish cities were taken as a reference in determining the boundaries of the historical urban patterns of the selected cities.

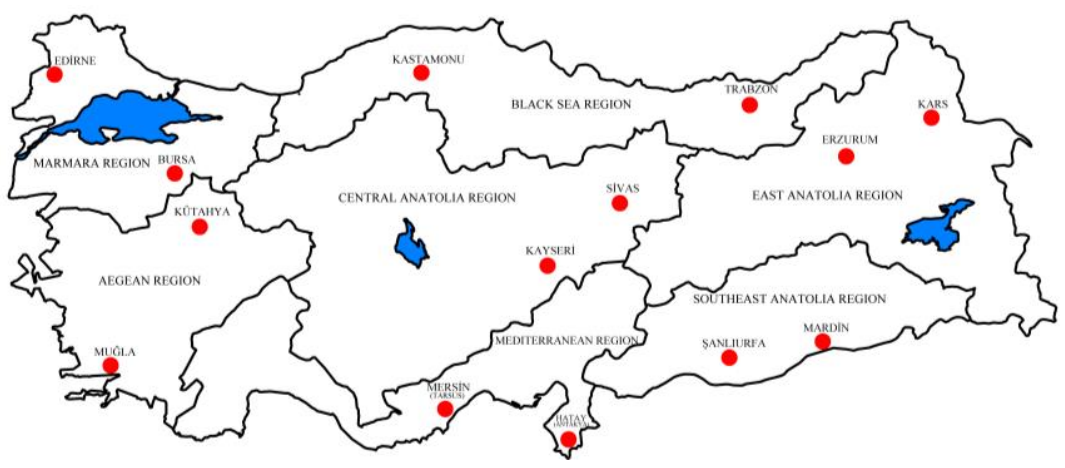

\section{The Marmara Region;}

Edirne; Geographically, it is located in the north eastern most tip of Turkey. Its winters are warm while its summers are extremely hot and dry (Bölük, 2016). Throughout its history, it has come under Roman, Byzantine 395 C.E., Ottoman 1362 C.E., and Turkish 1922 C.E. rule. It bears marks of predominantly Roman and Ottoman impact. It was built, for defense purposes, within a rectangular castle on a flatland during the Roman era. Being the
Figure 1. Locations of the selected sample areas on a map of Turkey. 
capital city of the Ottoman era, Edirne spread radially to the plains around the center to the east of the castle (Aru, 1998). The historical center of the city of Edirne is composed of two parts. These could be termed inner castle and outer castle. Accordingly, we can observe a grid-like road pattern inside the castle while we can see an organic road pattern outside the castle (Figure2).

Bursa; Geographically, this city is located in the interior of north east of Turkey. Its winters are warm whereas its summers are very hot and dry (Bölük, 2016). The city was built within a castle belonging to the Roman period on a slope at the foothills of Uludag. In the historical process, the city has come under Roman, Byzantine 395 C.E., Seljuk 1080 C.E., Ottoman 1362 C.E. and Turkish Republic 1922 C.E. rule. Although it has come under the influence of various civilizations, the Ottoman impact makes itself manifested more predominantly (Aru, 1998). Patterns belonging to the Ottoman period that are in parallel with the topography are visible. The city failed to maintain the grid-like road pattern of the Byzantine period. The organic urban pattern is dominant (Figure2).
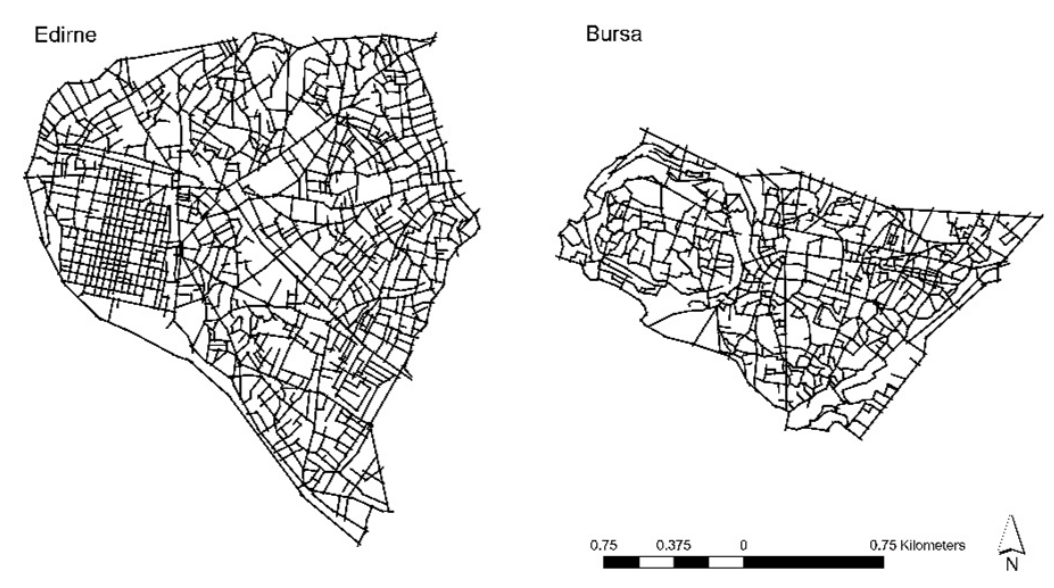

Figure 2. The road patterns of the cities of Edirne and Bursa.

\section{The Black Sea Region;}

Kastamonu; Geographically, this city is situated in the Karaçomak valley at the foothills of the Ilgaz Montains in the North-central part of Turkey. It enjoys warm winters and summers and has precipitation at all seasons (Bölük, 2016). It was located initially on the western slopes of a creek that divided the city into two but then extended from the flatlands on both banks to the steep slopes (Aru, 1998). In the historical process, it has come under Roman 100 B.C.E., Byzantine 395 C.E., Çobanoğulları principality 1295 C.E., Candaroğulları principality 1039 C.E., Ottoman1461 C.E., and Turkish Republic 1922 C.E. rule. However, the city created its present visible settlement pattern during the Ottoman period. Therefore, the visible form is an organic pattern (Figure 3). 
Trabzon; Geographically, the city is located inthe north-eastern part of Turkey. It enjoys warm winters and very hot summers, with a climate characterized by precipitation at all seasons (Bölük, 2016). In the historical process, the city has come under Greek 756 B.C.E., Roman 100 B.C.E., Byzantine 395 C.E., Greek-Pontic 1204 C.E., Ottoman 1461 C.E. and Turkish Republic 1922 C.E. rule (Aru, 1998). One can see spatial traces of all periods of the city, which has been under the influence of various civilizations. This situation results from the topographic structure of the city and the fact that it has been seen as a safe settlement due to the relationship this topography has established with the sea. The most obvious indication of this is the fact that the area where the city was first founded was between two deep valleys, which rendered it defensible and suitable for settlement (Dursun, 2002). The city displays an urban configuration that is squeezed between the sea and the mountains in the north-south axis and the flatlands betwen two deep valleys in the east-west axis (Figure3).
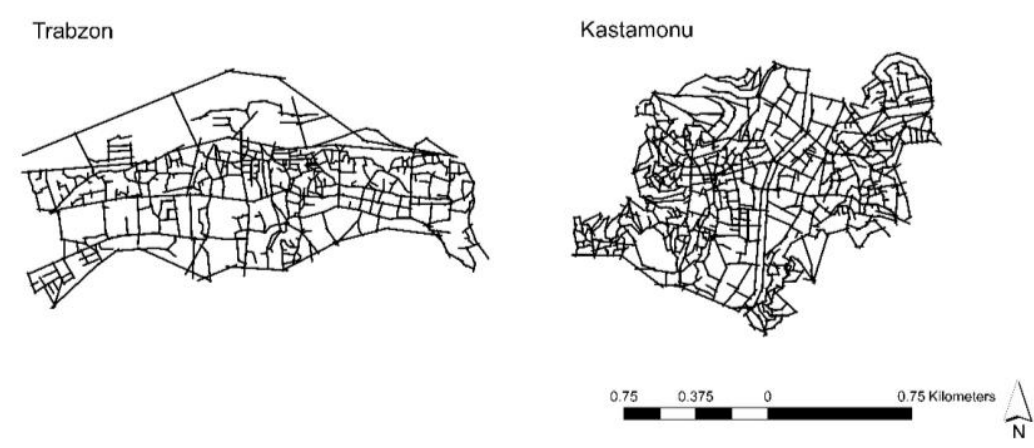

\section{The Central Anatolia Region;}

Kayseri; Geographically, the city is located in central Turkey. It enjoys warm winters and very hot and dry summers (Bölük, 2016). It was founded on the edge of a plain at the foothills of Erciyes Mountain in the Hittite period. It has been under the influence of numerous civilizations up to the present time. In the historical process, it has been ruled by the Greeks 756 B.C.E., Romans 100 B.C., Byzantines 395 C.E., Arabs 7th century, Ilkhanids 11th century, Eretna principality 14th century, Karamanids 1419, Ottomans 1515 C.E. and Turkish Republic 1922 C.E. (Aru, 1998). The historical pattern of the city reflects a radial growth. Its growth pattern begins with the castle at its center and expands in the form of concentric rings (Figure 4).

Sivas; The city is located on a slight slope to the north of the Kizilirmak valley. It is at an elevation of 1285 meters and has a rather harsh and cold climate. It enjoys extreme winters and dry and cool summers (Bölük, 2016). Its history dates back to the period of the Hittites. In the historical process, the city has come
Figure 3. Road patterns of the cities of Trabzon and Kastamonu 
under Hittite, Urartean, Median, Byzantine 395 C.E., Umayyid 7th century, Danişment principality 1080 C.E., Seljuk 1175 C.E., Ottoman1398 C.E. and Turkish Republic 1922 C.E. rule (Aru, 1998). Having been ruled by various civilizations, the city of Sivas bears marks of Roman, Seljuk and Ottoman periods (Figure 4).

Figure 4. The road patterns of the cities of Kayseri and Sivas
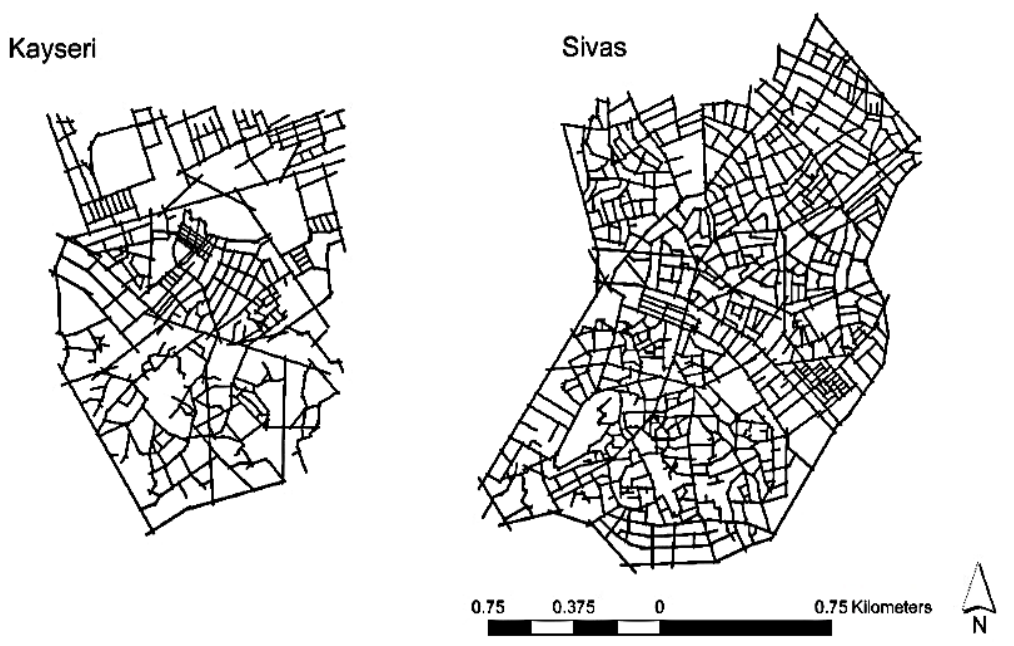

\section{The Eastern Anatolia Region;}

Kars; Geographically, it is located in the northern most tip of East Anatolia. Its winters are extreme and it enjoys a cool climate characterized by precipitation at all seasons (Bölük, 2016). The foundation of the city dates back to the Urartean times. The first settlement took place inside the Kars castle, but then the city grew in the vicinity of the castle. In the historical process, the city has come under the domination of Urarteans, Hurris, Sycthians, Sasanids 410 C.E., Seljuks 1064 C.E., Moguls 1239 C.E., Karakoyunlus 1406 C.E., Akkoyunlus 1467 C.E., Ottomans 1535 C.E., Russians 1877 C.E., and Turkish Republic 1922. Although it has come under the domination of many states, the city manifests impact of Ottoman (1535-1877) and Russian (1877-1922) periods. However, the grid-like pattern of the Russian period is observed more predominantly (Figure 5).

Erzurum; Located in the north eastern part of Turkey, the city was built inside and around a castle belonging to the Roman period. In the historical process, it has come under the rule of Romans 1st century B.C.E., Arabs 633 C.E., Seljuks 1048 C.E., Ilkhanids 1242 C.E., Karakoyunlus, Akkoyunlus 1335, Ottomans 1514 C.E. and the Turkish Republic 1922 C.E. (Aru, 1998). It exhibits a concentric development imposed by its topographic structure (Figure 5). Situated on a slope, the city is surrounded by mountains to its south and a flat plain to its north. An organic pattern is observed in the city. It has extreme winters and dry and cool summers (Bölük, 2016). 


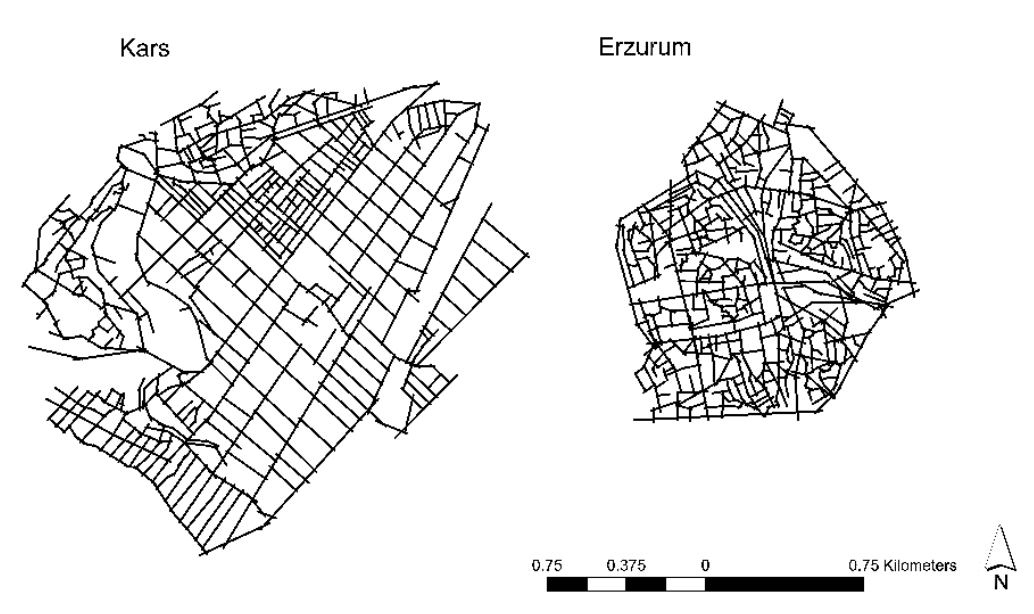

The Aegean Region;

Kütahya; The city is located in the interior of western Anatolia. It enjoys warm winters and warm and dry summers (Bölük, 2016). In the historical process, it has come under the rule of Romans 2 nd century B.C.E., Byzantines 395 C.E., Seljuks 1080 C.E., Germiyanoglus 1285 C.E., Ottomans 1381 C.E. and the Turkish Republic 1922 C.E. (Aru, 1998). The city bears marks of Romans, Byzantines, Seljuks, Germiyanoglus and Ottomans. The city was built in an arrowshaped manner in line with its topography on the slopes of a steep hill where the Byzantine castle was located. The city exhibits a radial system, Ulucami (The Grand Mosque) being at its center (Figure 6).

Muğla; Geographically, the city is located in the southwest of Anatolia. It was built on a slope at the foothills of Oyluk mountain. Two streams divide the city into three sections. The road system was not formed in parallel with the topography. It enjoys warm winters and very hot and dry summers (Bölük, 2016). In the historical process, the city has come under Roman 2nd century C.E., Byzantine 395 C.E., Arab 639 C.E., Seljuk 1069 C.E., Menteşeoğulları 1280 C.E., Ottoman 1390 C.E. and Turkish Republic 1922 C.E. rule (Aru, 1998). Although it has come under the influence of various civilizations, organic Ottoman pattern is felt in the urban form (Figure 6).
Figure 5. The road patterns of the cities of Kars and Erzurum. 


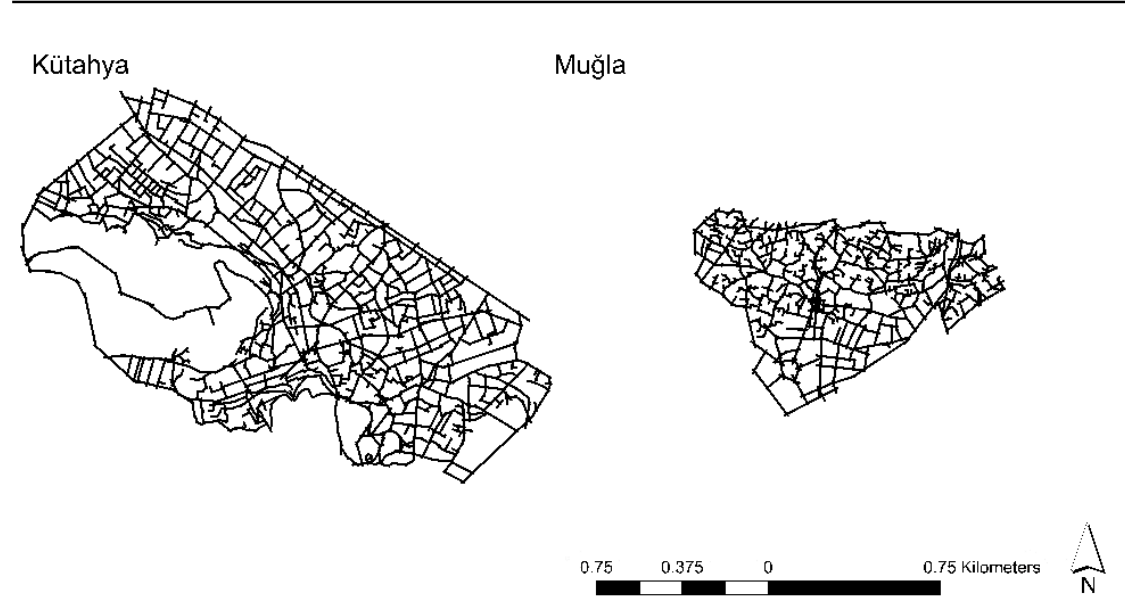

Figure 6. The road patterns of the cities of Kütahya and Muğla

\section{The Mediterranean Region;}

Tarsus; Tarsus is located in the central south section of the country. It enjoys warm winters and very hot and dry summers (Bölük, 2016). The historical center of Tarsus has a long-standing history dating back to thousands of years. The city was built at an intersection of important commercial roads in Cilician Plains to the south of the Taurus Mauntains and has maintained its existence from ancient times to the present. Because it has been a settlement since ancient times, it is rich in terms of cultural heritage. In subsequent periods, various different civilizations such as the Hittites, Assyrians, Egyptians, Persians, Greeks, Romans, Byzantines, Abbasids, Umayyids, Anatolian Seljuks and Ottomans ruled the city. The period whose marks are most clearly seen in the city center is the Ottoman period by virtue of the fact that it was the last state dominating the city before the declaration of the Republic (Figure 7)(Tüter \& Ökesli, 2015).

Antakya; Geographically, the city is located in the southernmost tip of Turkey. It enjoys warm winters and very hot and dry summers (Bölük, 2016). In the historical process, the city of Antakya has come under the rule of Seleucids 312 B.C.E., Romans 64 B.C.E., Arabs 638 C.E., Crusaders 1098 C.E., Mameluks 1268 C.E., Ottomans 1516 C.E., The French 1918 C.E. and the Turkish Republic 1938 C.E. The historical core of the city was built on a slope between the terraces created by the River Asi and Mount Habibi Neccar. The city earned its importance during the Roman Empire. It was the third biggest city in the Roman Empire. In subsequent periods, the spatial configuration of the Roman period changed under the influence of various cultures (Demir, 1996). The city acquired an Islamic pattern especially after it came under Arab domination. It maintained this pattern during the subsequent Ottoman period. The pattern of Antakya still bears the marks of its early Hellenistic and Roman structures, especially in the formation of geometrical grids. The configuration of the streets reinforces Islamic 
characteristics; culde-sacs mean privacy and street structure is narrow (Figure 7).

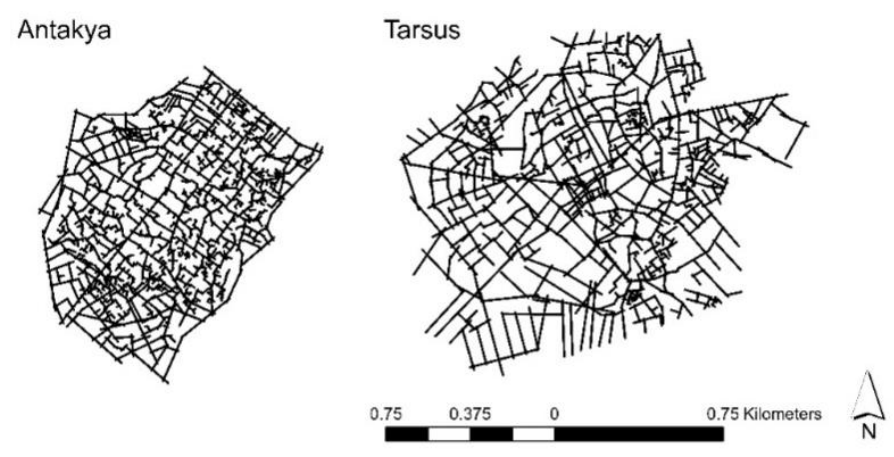

The South Eastern Anatolia Region;

Urfa; Urfa is one of the oldest centers of civilization on earth. Natural conditions that are conducive to settlement and its position at the intersection of roads led to the emergence of various cultures. In the historical process, it has come under the domination of Assyrians, Persians 6th century B.C.E, Seleucids 3rd century B.C.E., Romans 1st century C.E., Byzantines 395 C.E., Arabs 638 C.E., Hamdanis 873 C.E., Seljuks 11th century C.E., Karakoyunlus, Crusaders 1098 C.E., Ottomans 1516 C.E. and the Turkish Republic 1922 C.E.. In addition to housing the oldest civilizations of Anatolia, the cultural legacy left by Persians and Romans, who came to the area for purposes of invasion and settlement, was passed on to the Arabs and Turks, who later occupied the region, thereby contributing to the shaping of the unique culture of the city in the historical process (Figure 8). The city enjoys warm winters and very hot and dry summers (Bölük, 2016).

Mardin; Possessing an organic pattern, Mardin is a slope settlement and exhibited a linear growth along the slope for long periods due to its topographic characteristics (Yekbun \& Çırak, 2018). In the historical process, the city has come under the domination of Romans 1st century, Byzantines 395 C.E., Arabs 638 C.E., Hamdanis 873 C.E., Seljuks 11th century, Karakoyunlus, Artuklus 1408 C.E., Ottomans 1517 C.E., and the Turkish Republic 1922 C.E. (Aru, 1998). It displays a settlement fabric where each layer in the historical process is built upon the other. The urban conservation site of Mardin expanded when the settlement pattern began to extend from within the fortress to the outer city walls (Figure 8). A unique organic pattern emerged when, in harmony with the topography, this traditional fabric gave way to terraced housing that did not block each other's façades. The building-backyardgarden-street interaction, which was compatible with the city's natural topographic characteristics and cultural life, created an
Figure 7. The road patterns of the cities of Tarsus and Antakya 
unprecendented landscape. The city enjoys warm winters and very hot and dry summers (Bölük, 2016).

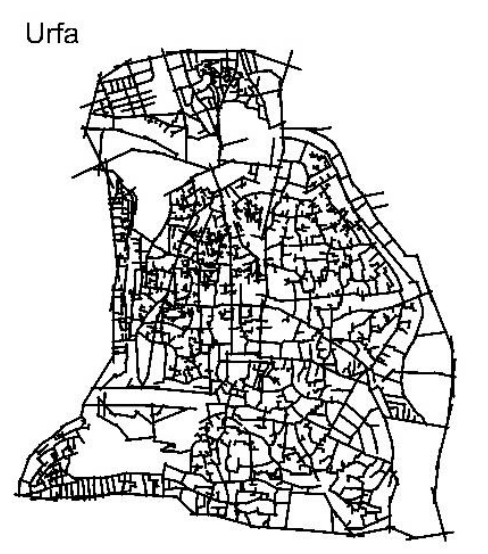

Mardin

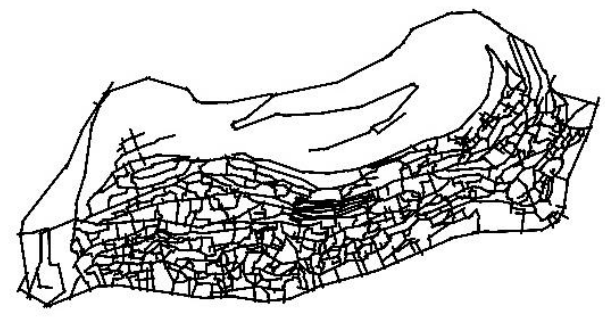

Figure 8. The road patterns of the cities of Urfa and Mardin

\section{METHODOLOGY}

According to Hillier and Hanson (1984), the space syntax approach bases urban structure on generation of a spatial culture (Hillier \& Hanson, 1984). Studies conducted on urban morphology investigating especially historical cores of cities attributed the characteristics of the historical spaces to civilizations they hosted (Cutini, 2001; Hillier, 1989; Kubat, 1999; Peponis, Hadjinikolaou, Livieratos, \& Fatouros, 1989).

Therefore, concepts related to history and culture such as Roman city, Hellenistic city or Turkish city emerged in the evaluation of urban structures (Eskidemir, 2016). The space syntax method, which approaches urban morphology from a scientific perspective, plays an active role in process-based investigation of transformations of historical cores. In this way, historical developments of cities are analyzed, and the harmony between spatial structure and social structure is revealed. The process of morphological evolution of the city is analyzed via this method, but other factors such as functions within the city are also incorporated into these analyses, thereby helping obtain data based on different factors. Space syntax explains morphological development of cities on the basis of spatial configuration and interprets the relationships among the factors involved in the formation of spatial configuration of the city. It interprets these spatial analyses through numerical values and thus provides verifiable data (Kubat, 1997). This methodology contributes greatly to the understanding of the physical structure of the cases in this study. 
It is possible to give quantitative descriptions of built spaces. Some definitions of the methodology used in the study are as follows: The axial map is the basis of settlement layout analysis. This represents the distance up to which observers can have an uninterrupted impression of visibility and permeability as they move about the town and look in various directions. The map is derived by drawing the fewest and the longest lines of uninterrupted permeability necessary to cover the public open space of an area.

The size of a settlement system is measured in terms of the number of lines. The convex map of a settlement is the set of widest spaces that covers the open space structure of that settlement. It is a map of the open space broken up into the widest possible convex spaces. If the system is regular, many axial lines may pass through a series of convex spaces. From these maps, it is easy to see that urban space structures differ from one another according to the degree of axial and convex extensions of their parts and according to the relation between these two forms of extension (Batty \& Rana, 2002; Hillier \& Hanson, 1984; Osmond, 2011).

In this context, first, the concept of syntactic analysis developed by Hillier was implemented in this study on the basis of a methodological approach proposed by Kubat (Hillier \& Hanson, 1984; Kubat, 1997). In this framework, parameteres were grouped into three main categories. These categories were convex space analyses, axial space analyses and syntactic space analyses. Convex space analyses were measured through the parameters of convex articulation, convex deformation of the grid, grid convexity and convex ringness. The second category, namely axial space analyses involve the parameters of axial articulation, axial integration of convex space, grid axiality and axial ringness. The syntactic parameters in the last category, on the other hand, involve the parameters of integration, intelligibility and synergy. The study compared the historical cores of the selected sample cities on the basis of eleven parameters.

\section{Measures of Convexity;}

Convex articulation can be measured by dividing the number of convex spaces by the number of buildings. The degree to which the open space of an urban system is broken up into convex space is indicated by the convex articulation value. Lower values indicate lesser break up and therefore more synchrony (Figure 9). Convex articulation $=C$ /number of buildings, $C$ is the number of convex spaces (Kubat, 1997). 
Figure 9. Convex articulation (Thilagam \& Banerjee, 2016).

Figure 10. Convex deformation of grid (Thilagam \& Banerjee, 2016).

Figure 11. Grid convexity (Thilagam \& Banerjee, 2016).
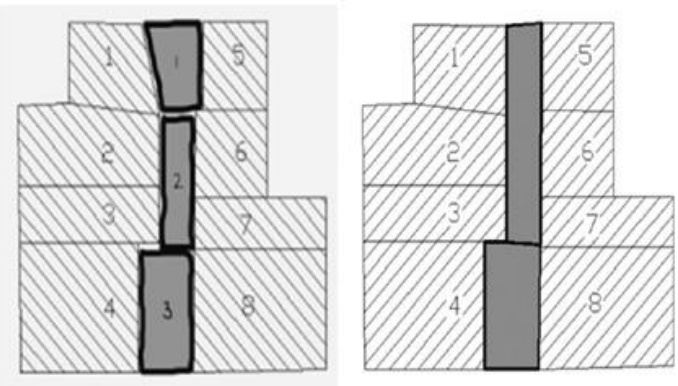

Convex deformation of the grid can be measured by dividing the number of convex spaces (C) by the number of islands (I) (Figure 10). Wherein an island is defined as a block of continuously connected buildings completely surrounded by open space. Convex deformation $=C / I$, (Kubat, 1997).
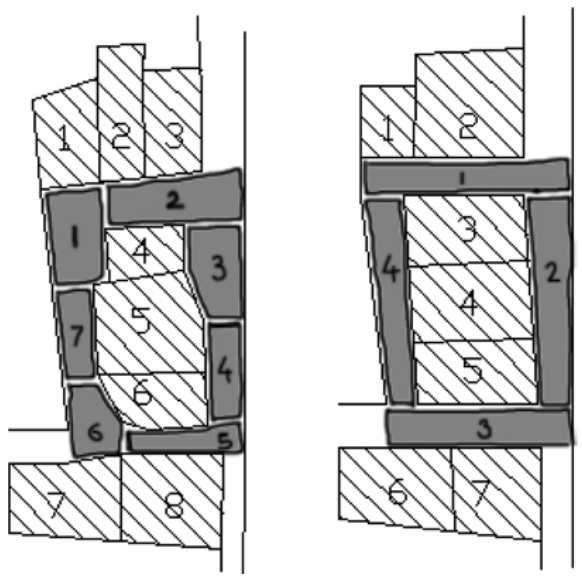

Grid convexity (Gconvex) of the system is measured by the formula Grid convexity $=\left(I^{1 / 2}+1\right)^{2 / c}$, where $I$ is the number of islands and $C$ is the number of convex spaces. It is possible to make a comparison of a convex map with an orthogonal grid in which convex spaces extend across the system in one direction, and in the other direction fit ladder fashion into the interstices (Figure 11). High values indicate little deformation of the grid and low values indicate higher deformations of the grid (Kubat, 1997).
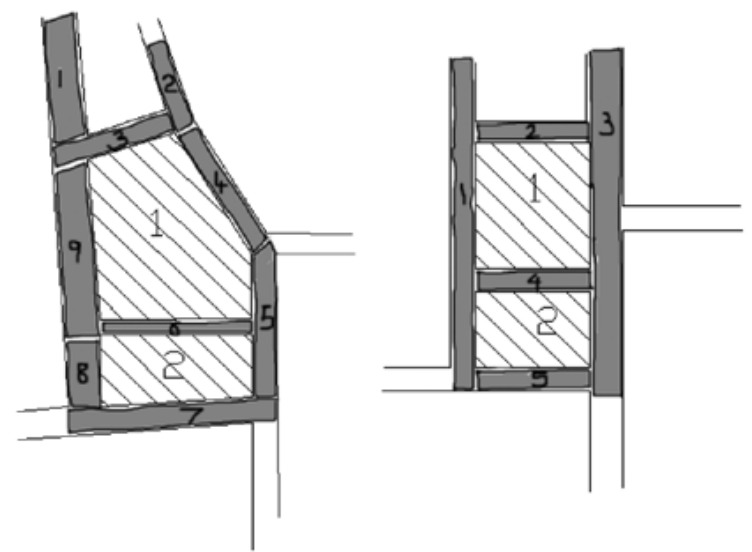
Convex ringiness; The ringiness of the convex system, ( $R$ convex) is the number of the rings in the system as a proportion of the maximum possible planar rings for that number of spaces. $R$ convex $=I / 2 C-5$, where $I$ is the number of islands and $C$ is the number of convex spaces.

\section{Measures of Axiality}

Axial articulation can be measured by dividing the number of axial lines by the number of buildings. Low values indicate a high degree of axiality and high values indicate a greater break up(Figure 12)(Kubat, 1997). Axial articulation $=L /$ the number of buildings, where $L$ is the number of axial lines.
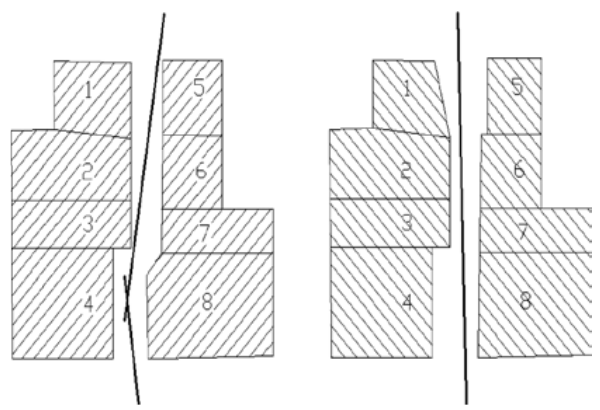

Axial integration of convex spaces can be measured by dividing the number of axial lines by convex spaces (Figure 13). Low values indicate a higher degree of axial integration of convex spaces (Kubat, 1997). Axial integration $=L / C$, where $L$ is the number of axial lines and $C$ is the number of convex spaces.
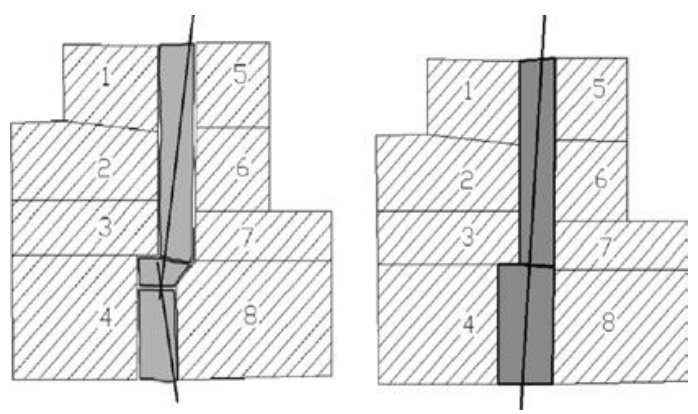

The grid axiality (Gaxial) of the system gives a measure of the comparison of an orthogonal grid with the number of islands (Figure 14). The value is between 0 and 1 , and a high value indicates a strong approximation to a grid and a low value a greater degree of axial deformation (Kubat, 1997). Grid axiality $=2 I^{1 / 2}+2 / L$, where $I$ is the number of islands and $L$ is the number of axial lines
Figure 12. Axial articulation (Thilagam \& Banerjee, 2016).

Figure 13. Axial integration of convex spaces (Thilagam \& Banerjee, 2016). 
Figure 14. The grid axiality (Thilagam \& Banerjee, 2016).

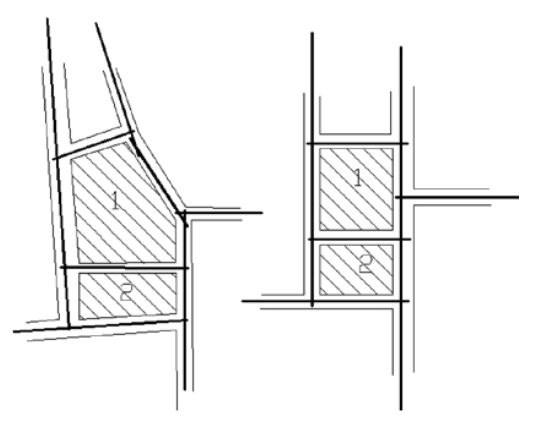

The ringiness of the axial map (Raxial) can be measured by the formula $R$ axial $=\mathrm{I} / 2 L-5$, where $I$ is the number of islands and $L$ is the number of axial lines. As the axial map is nonplanar, this value will be higher than the convex value. From the relation between convexity and axiality in a space, we obtain two kinds of information about the space: through the convex organization, we are given complete local information about the space we are in, and through the axial organization, we are given partial global information about the spaces we might go to. In urban space, we are in effect given information about two scales at once.

\section{Syntactic Measures}

The central concept of space syntax is integration. The technique allows one to express integration in numerical values. As is the case with many other measures of spatial structure, these values are dependent upon the urban area. The integration of space is a function of the mean number of lines and changes of direction that need to be taken to go from that space to all other spaces in the settlement system. Integration is therefore about syntactic not metric accessibility, and the word 'depth' rather than 'distance' is used to describe how far a space lies. Every line in a settlement layout has a certain depth from every other line. The integration value of a line is a mathematical way of expressing the depth of that line from all other lines in the system. It is assumed that the distribution of integration across an urban area correlates with the movement pattern of an area. Urban areas can be distinguished by and compared in terms of different levels of integration. Integration has is used as a measure of quality for urban areas. By calculating integrated and segregated parts of a settlement, it is also possible to know whether a new design proposal fits into the existing structure of an area.

The syntactic intelligibility of an urban system is defined as the degree of correlation between the connectivity and integration values in the system. The term intelligibility is used because the stronger the correlation, the easier it is to infer the global position of a space from its directly observable local connections (Bafna, 2003; Hillier, 1999; Hillier \& Hanson, 1984; Penn, Hillier, Banister, 
\& Xu, 1998). This makes it possible to capture the way people can learn about large patterns from their experience of small parts or fail to do so when the correlation is weak (Hillier \& Hanson, 1984).

The concept of synergy, like the parameter of intelligebility, has been defined as a second-degree value emerging as a result of correlation. It is obtained as a consequence of the correlation between global integration (Rn) and local integration (R3) parameters where the city is assessed at the local scale dimension. The synergy value measures the degree of an area or a space within the urban system and to what extent it is correlated with this system (Hillier, 1996, 1999). The higher the correlation, the more the local areas in the system make themselves available as a well-structured local aggregation of the urban grid. In other words, the whole system tends to be made up of powerful local centers (Asami, Kubat, \& Istek, 2001).

If the values which these two parameters, i.e. intelligebility and synergy, have are between 1 and 0.45 , then the settlement is interpreted to be intelligible or effective in the settlement fabric of a local scale; if it is between 0.45 and 0.2 , then it is interpreted to be an average value and if it is lower than 0.2 , then it is interpreted to be unintelligible (Choudhary \& Adane, 2012; Kubat, 1997; Mohareb, 2009).

\section{FINDINGS OF THE STUDY}

The data collection stage occupies a significant place in the study in order to be able to implement the analyses mentioned in the methodology section. For the purpose of our this study, the map of urban space is converted into two types of maps: an axial map whose basic unit is the axial line and a convex map whose basic unit is a two-dimensional polygon-shaped convex space. The base maps are digitized using Qgis software program and converted into dxf output files which are loaded into Depthmap software version x 0.30 (Varoudis, 2012) to conduct the axial and convex analysis. The axial analysis method was used in the study, because axial analysis needs to be used in the convex space relationship since convex space analyses and axial space analyses are made comparatively in the study. Numbers of convex spaces, numbers of axial lines, numbers of building and numbers of building islands were calculated in each of the fourteen cities selected to make the specified analyses and, in the areas, covering the boundaries of historical urban cores (Table 1). In the next stage, each of the parameters were analyzed separately. 
Table 1. Characteristic measures for comparison of the morphology of the selected cities

\begin{tabular}{|c|c|c|c|c|}
\hline \multirow{2}{*}{$\frac{\text { Selected }}{\underline{\text { Cities }}}$} & \multicolumn{4}{|c|}{ Urban form data } \\
\hline & $\begin{array}{c}\text { Number of } \\
C=\text { Convex Space }\end{array}$ & $\begin{array}{c}\text { Number of } \\
\text { L=Axial Line }\end{array}$ & $\begin{array}{c}\text { Number of } \\
\text { B=Building }\end{array}$ & $\begin{array}{c}\text { Number of } \\
\text { I=Island }\end{array}$ \\
\hline Edirne & 1132 & 1237 & 18690 & 602 \\
\hline Bursa & 1214 & 1183 & 12700 & 318 \\
\hline Katsamonu & 913 & 943 & 3564 & 310 \\
\hline Trabzon & 565 & 702 & 3761 & 173 \\
\hline Sivas & 1694 & 980 & 8327 & 672 \\
\hline Kayseri & 415 & 446 & 5197 & 165 \\
\hline Kars & 778 & 455 & 7826 & 352 \\
\hline Erzurum & 1188 & 553 & 9113 & 300 \\
\hline Kütahya & 1037 & 1158 & 2259 & 345 \\
\hline Mugla & 648 & 786 & 3987 & 392 \\
\hline Urfa & 1739 & 2413 & 14571 & 315 \\
\hline Mardin & 2159 & 1476 & 13254 & 268 \\
\hline Antakya & 1224 & 1089 & 1880 & 256 \\
\hline Tarsus & 960 & 811 & 3056 & 304 \\
\hline Mean & 1119 & 1017 & 7728 & 341 \\
\hline
\end{tabular}

\section{Convex Space Analysis}

When the fourteen selected cities ara analyzed according to the convex space parameters (Figure 15), low values in convex articulation indicate less breakup, which in turn indicates a more synchronous system. When convex articulation values of the historical cores of the selected cities are compared, it is observed that Edirne, Bursa, Trabzon, Sivas, Kayseri, Kars, Erzurum, Muğla, Urfa and Mardin have lower convex articulation values than the average compared with Kastamonu, Antakya, Kütahya and Tarsus $(0,210)$, which means that they are more synchronous cities. It can be said that the historical urban core of Edirne has the lowest value $(0,061)$ and therefore it is the city that possesses the most synchronous structure. Likewise, Antakya has the highest value $(0,651)$ and therefore it could be said to be the least synchronous city among the sample cities (Table 2).

When values of convex deformation of the grid, which is another parameter, are examined, it is seen that the cities of Bursa, Erzurum, Urfa, Mardin and Antakya are above the average (3.521), whereas the cities of Edirne, Kastamonu, Trabzon, Sivas, Kayseri, Kars, Kütahya, Muğla and Tarsus possess lower grid deformation (Table 2). High convex deformation values of the grid system indicate a more irregular open space system. It could be said that the historical core of the city of Mardin has the highest value and therefore possesses the most irregular open space system. In contrast, the historical urban core of the city of Muğla, which has 
the lowest value, exhibits a more regular pattern compared with the other cities. When viewed from a regional perspective, it could be said that while the cities in the Aegean, Central Anatolian and Black Sea Regions exhibit a more regular form, the cities in the East Anatolia and Marmara Regions have values closer to the average, and the cities in the South Eastern Anatolia Region have a more irregular form than the average.

High values in the grid convexity parameter indicate low deformation in the grid structure. When the cities of the sample are examined in terms of grid convexity, it is seen that grid convexity values of the cities of Edirne, Kastamonu, Sivas, Kayseri, Kars and Muğla are above the average, whereas grid convexity values of Bursa, Trabzon, Erzurum, Kütahya, Urfa, Mardin, Antakya and Tarsus are below the average (Table 2). Grid convexity values in Muğla, Edirne and Kars are higher when compared with the values in the other cities. This indicates that the grid structure is less broken. When the matter is examined from a regional perspective, it could be said that grid structure is the least broken in the Central Anatolia Region, wheras grid structure is the most broken in the South eastern Anatolia Region.

High values in the convex ringness parameter indicate a more grid-like system than the organic pattern in terms of the open space system. At this point, when the grid ringness values are examined, it is seen that, proportionately, they exhibit the same values as grid convexity values. The results indicate that grid structure is higher in the historical urban patterns of Edirne, Kars and Muğla (Table 2).

Table 2. Measures of Convexity Parameters of selected cities' historical cores

\begin{tabular}{|c|c|c|c|c|}
\hline$\underline{\text { Cities }}$ & $\begin{array}{c}\text { Convex } \\
\text { Articulation } \\
(\text { Num. of } C / \text { Num. of } B)\end{array}$ & $\begin{array}{c}\text { Convex } \\
\text { Deformation of Grid } \\
\text { (Num. of C / Num. of I) }\end{array}$ & $\begin{array}{c}\text { Grid } \\
\text { Convexity } \\
((I 1 / 2+1) 2 / C)\end{array}$ & $\begin{array}{c}\text { Convex } \\
\text { Ringness } \\
I / 2 C-5\end{array}$ \\
\hline Edirne & 0.061 & 1.880 & 0.576 & 0.266 \\
\hline Bursa & 0.096 & 3.818 & 0.292 & 0.131 \\
\hline Kastamonu & 0.256 & 2.945 & 0.379 & 0.170 \\
\hline Trabzon & 0.150 & 3.266 & 0.355 & 0.154 \\
\hline Sivas & 0.203 & 2.521 & 0.428 & 0.199 \\
\hline Kayseri & 0.080 & 2.515 & 0.462 & 0.200 \\
\hline Kars & 0.099 & 2.210 & 0.502 & 0.227 \\
\hline Erzurum & 0.130 & 3.960 & 0.283 & 0.127 \\
\hline Kütahya & 0.459 & 3.006 & 0.369 & 0.167 \\
\hline Mugla & 0.163 & 1.653 & 0.668 & 0.304 \\
\hline Urfa & 0.119 & 5.521 & 0.202 & 0.091 \\
\hline Mardin & 0.163 & 8.056 & 0.140 & 0.062 \\
\hline Antakya & 0.651 & 4.781 & 0.236 & 0.105 \\
\hline Tarsus & 0.314 & 3.158 & 0.354 & 0.159 \\
\hline MeanValues & 0.210 & 3.521 & 0.375 & 0.169 \\
\hline
\end{tabular}


Figure 15. Convex maps of the selected cities' historical cores
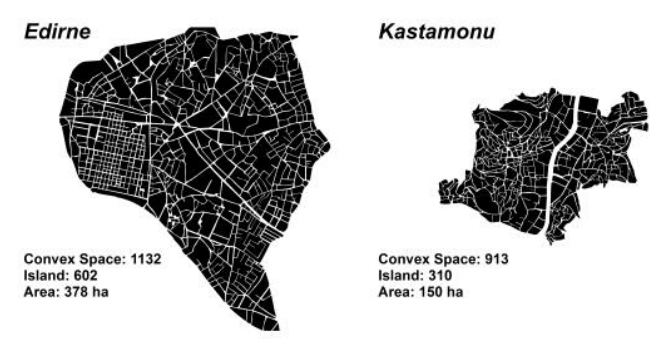

Trabzon

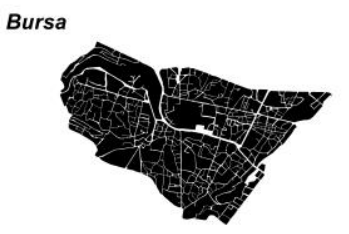

Convex Space: 1214
Island: 318
Area: 202 ha

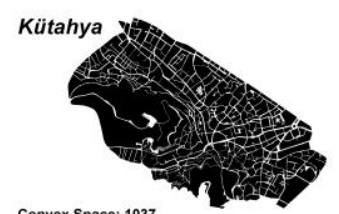

Convex Space:
Island: 345
Area: 216 ha

Muğla

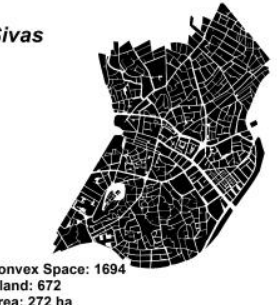

Kayseri

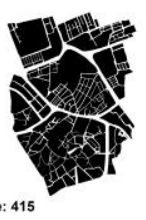

Convex Space:
Island: 165
Area: 127 ha

Tarsus

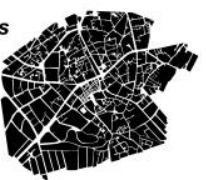

Convex Space: 960
Island: 304 Convex Space: 648
Island: 392
Area: 67 ha Area: 176 ha

Erzurum

Convex Space: 11
Island: 300

Urfa

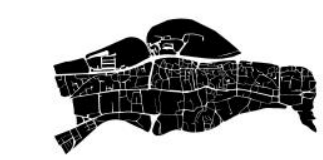

Convex Space: 565 Island: 173
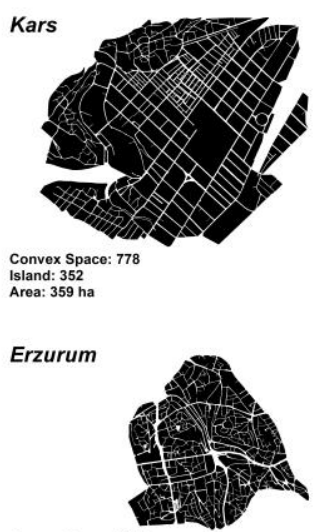

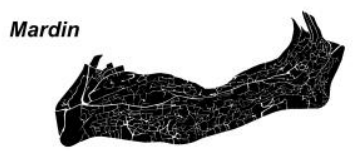

Convex Space: 2159
Island: 168
Area: 111 ha

\begin{tabular}{lllll}
0.20 .4 & 0.8 & 1.2 & 1.6 & 2 \\
\hline
\end{tabular}

\section{Axial Space Analysis}

When the fourteen selected cities are analyzed according to the parameters of axial space (Figue 16), it is seen that Kastamonu, Kütahya, Antakya and Tarsus are above the average in terms of axial articulation. In contrast, when compared with these cities, Edirne, Bursa, Trabzon, Sivas, Kayseri, Muğla, Kars, Erzurum, Urfa and Mardin have lower articulation values than the average (0.197). High axial articulation values indicate high axial breakup. Kars, Erzurum and Edirne stand out as the historical cities where proportionately axial breakup is the lowest. Antakya, on the other hand, is the city with the highest axial breakup. When viewed from a regional perspective, it can be said that open space systems of 
historical cores of the cities chosen from the Marmara, Central Anatolia and Southeastern Anatolia Regions exhibit a more axial structure. Likewise, breakups were higher in number in the historical cores of the cities chosen from the Mediterranean Region (Table 3).

When values of axial integration of convexity, which is another parameter, are examined, it is observed that Edirne, Bursa, Kastamonu, Trabzon, Kayseri, Kütahya, Muğla and Urfa are above the average, whereas Sivas, Kars, Erzurum, Mardin, Antakya and Tarsus are below the average in this respect. This parameter makes a comparison between the number of axial lines and the number of convex spaces, and here low values indicate a high level of integration of convex space. When looked in detail, proportionately, the highest level of axial integration is observed in the cities of Urfa, Trabzon and Muğla. It is also seen that the lowest axial integration is in the cities of Erzurum, Kars and Sivas. When viewed from a regional perspective, it can be said that historical fabrics of the cities in the Marmara, Black Sea and Aegean Regions have low axiality, whereas the historical fabrics of the cities in the Mediterranean and Eastern Anatolia Regions have high levels of axiality (Table 3).

The grid axiality value enables us to compare the same number of building islands as the orthogonal grid in the urban system. Here, high values point to a stronger grid structure. When the cities in the sample are examined in terms of the grid axiality parameter, it is seen that the grid axiality values of the cities of Sivas, Kayseri, Kars, Erzurum, Muğla and Tarsus are above the average, while grid axiality values of Bursa, Kastamonu, Trabzon, Kütahya, Muğla, Urfa, Mardin and Antakya are below the average (Table 2). However, given that these values are between 0 and 1, if they are near 1 , they begin to express a grid system. Since the values in the sample are 0.1 and below, they can be deemed as systems whose grid axiality has been deformed (Table 3).

High values in the axial ringiness parameter indicate a more gridlike system compared with organic pattern in terms of open space system. At this point, when axial ringiness values are examined, it is seen that values of the cities of Edirne, Sivas, Kars and Erzurum are above the average value. This indicates that grid structure is higher in these cities than that in the other cities (Table 3). 
Table 3. Measures of Axiality Parameters of selected cities' historical cores

\begin{tabular}{lcccc}
\hline \multicolumn{1}{c}{ Cities } & $\begin{array}{c}\text { AxialArticulation } \\
\text { (Num. of L/Num. of } B)\end{array}$ & $\begin{array}{c}\text { Axial Integration of } \\
\text { Convexity } \\
\text { (Num. of L / Num. of C) }\end{array}$ & $\begin{array}{c}\text { Grid Axiality } \\
\left(2 \mathrm{I}^{1 / 2}+2 / \mathrm{L}\right)\end{array}$ & $\begin{array}{c}\text { Axial Ringness } \\
(\mathrm{I} / 2 \mathrm{~L}-5)\end{array}$ \\
\hline Edirne & 0.066 & 1.093 & 0.041 & 0.244 \\
Bursa & 0.093 & 0.974 & 0.032 & 0.135 \\
Kastamonu & 0.265 & 1.033 & 0.039 & 0.165 \\
Trabzon & 0.187 & 1.242 & 0.040 & 0.124 \\
Sivas & 0.118 & 0.579 & 0.055 & 0.344 \\
Kayseri & 0.086 & 1.075 & 0.062 & 0.186 \\
Kars & 0.058 & 0.585 & $\mathbf{0 . 0 8 7}$ & $\mathbf{0 . 3 8 9}$ \\
Erzurum & 0.061 & 0.465 & 0.066 & 0.272 \\
Kütahya & 0.513 & 1.117 & 0.034 & 0.149 \\
Muğla & 0.197 & 1.213 & 0.053 & 0.250 \\
Urfa & 0.166 & $\mathbf{1 . 3 8 8}$ & 0.016 & 0.065 \\
Mardin & 0.111 & 0.684 & 0.024 & 0.091 \\
Antakya & $\mathbf{0 . 5 7 9}$ & 0.890 & 0.031 & 0.118 \\
Tarsus & 0.265 & 0.845 & 0.045 & 0.188 \\
\hline Mean Values & $\mathbf{0 . 1 9 7}$ & $\mathbf{0 . 9 4 2}$ & $\mathbf{0 . 0 4 5}$ & $\mathbf{0 . 1 9 4}$ \\
\hline
\end{tabular}

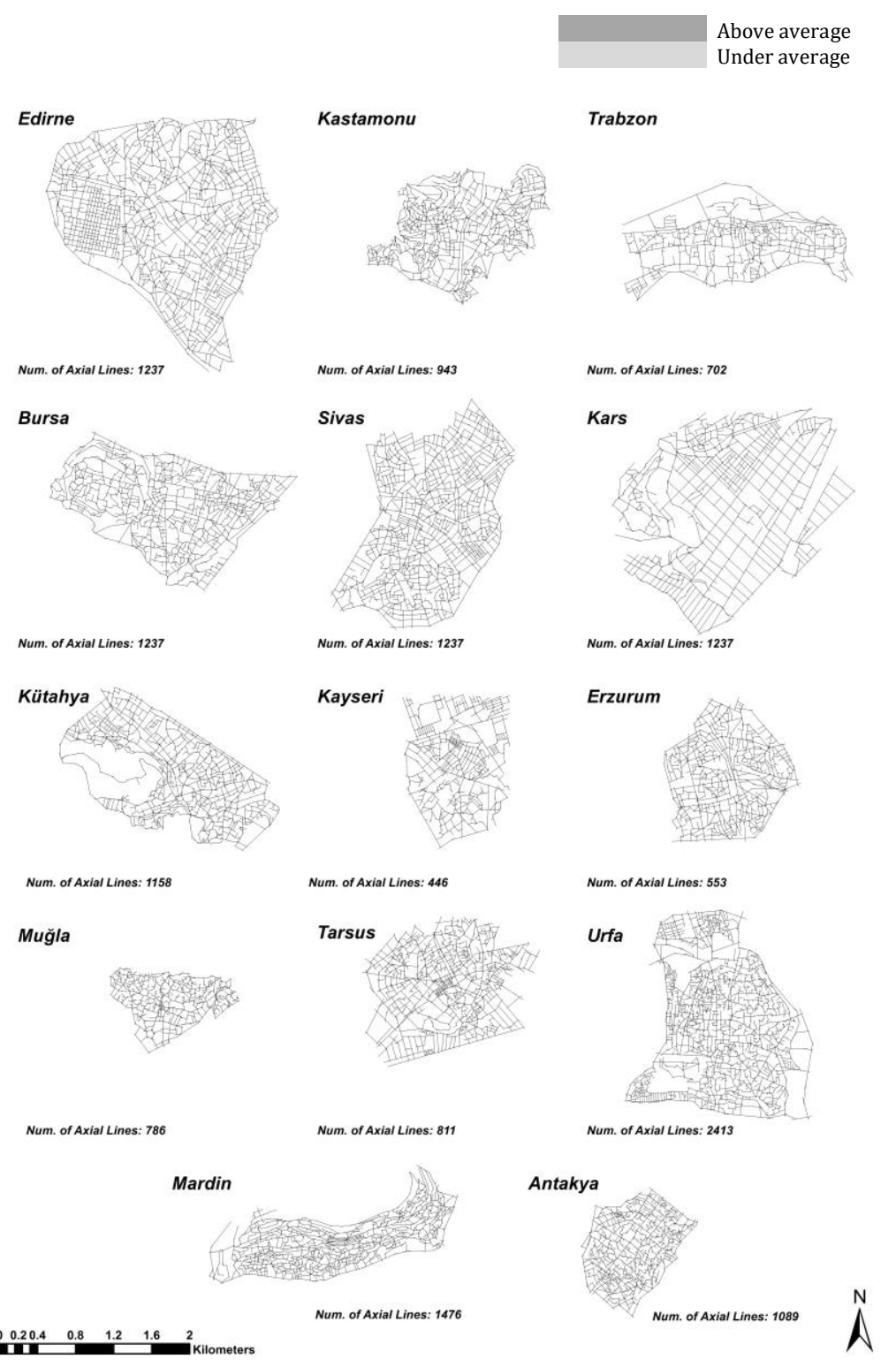




\section{Syntactic Measures of the Cities}

When the fourteen selected cities are analyzed according to syntactic parameters (Figue 17), it is seen that Sivas, Kayseri, Kars, Erzurum, Antakya and Tarsus have values above the average when integration values are assessed on a global scale (Rn) in terms of the selected cities. In contrast, the cities of Edirne, Bursa, Kastamonu, Trabzon, Kütahya, Muğla, Urfa and Mardin are below the average. High integration values indicate existence of a more accessible system within an urban system. It is observed that among the sample cities, the historical core ofthe city of Kars has the highest integration value with 1.117, whereas the historical core of the city of Mardin has the lowest integration value with 0.51 . When a comparison is made among the regions, it is seen that the mean integration values of the sample cities selected from the Marmara, Black Sea, Aegean and South Eastern Anatolia Regions are lower than the mean integration values of the cities selected from the Central Anatolia, Mediterranean and Eastern Anatolia Regions (Table 4).

When the cities are assessed in terms of intelligibility, which is another parameter, it is seen that Trabzon, Sivas, Kayseri, Kars, Erzurum, Kütahya, Muğla and Tarsus are above the average value of 0.453, whereas Edirne, Bursa, Kastamonu, Urfa, Mardin and Antakya are below this average value. High values of the intelligibility parameter indicate that spatial configuration is more intelligible and easily predictable by users. At this point, it could be said that the highest syntactic intelligibility value belongs tothe city of Tarsus with 0.621 . When the intelligibility parameter is compared in terms of the regions, it is observed that the values of the cities inthe Central Anatolia and Eastern Anatolia Regions are higher, whereas the values of the cities in the Marmara and South Eastern Anatolia Regions are lower (Table 4).

When the parameter of synergy, which is a correlation of local and global integration values, is examined, it is seen that values concerning the cities of Bursa, Trabzon, Sivas, Kayseri, Kars, Erzurum, Antakya and Tarsus are above the average value of 0.698, whereas the cities of Edirne, Kastamonu, Kütahya, Muğla, Urfa are Mardin are below the average. It is observed that the highest value is in Kars, while the lowest value is in Mardin (Table 4). 
Table 4. Space Syntax Parameters of selected cities' historical cores

\begin{tabular}{|c|c|c|c|c|c|}
\hline$\underline{\text { Cities }}$ & $\begin{array}{c}\text { Integration } \\
\text { (Global) }\end{array}$ & $\begin{array}{c}\text { Integration } \\
\text { (Local R3) }\end{array}$ & Connectivity & $\begin{array}{c}\text { Intelligibility } \\
\text { (Correlation between } \\
\text { Integration Global and } \\
\text { Connectivity) } \\
\end{array}$ & $\begin{array}{c}\text { Sinergy } \\
\text { (Correlation between } \\
\text { Integration Global and } \\
\text { Integration Local R3) } \\
\end{array}$ \\
\hline Edirne & 0.782 & 1.681 & 3.515 & 0.327 & 0.540 \\
\hline Bursa & 0.810 & 1.507 & 3.072 & 0.381 & 0.721 \\
\hline Kastamonu & 0.728 & 1.529 & 3.249 & 0.441 & 0.654 \\
\hline Trabzon & 0.812 & 1.431 & 2.932 & 0.469 & 0.714 \\
\hline Sivas & 0.994 & 1.701 & 3.465 & 0.478 & 0.723 \\
\hline Kayseri & 1.096 & 1.621 & 3.318 & 0.539 & 0.815 \\
\hline Kars & 1.117 & 1.794 & 3.635 & 0.521 & 0.834 \\
\hline Erzurum & 1.080 & 1.721 & 3.588 & 0.555 & 0.796 \\
\hline Kütahya & 0.663 & 1.432 & 3.054 & 0.465 & 0.683 \\
\hline Muğla & 0.555 & 1.324 & 2.863 & 0.490 & 0.659 \\
\hline Urfa & 0.594 & 1.283 & 2.629 & 0.307 & 0.553 \\
\hline Mardin & 0.510 & 1.346 & 2.847 & 0.335 & 0.496 \\
\hline Antakya & 0.854 & 1.393 & 2.714 & 0.409 & 0.748 \\
\hline Tarsus & 1.109 & 1.686 & 3.531 & 0.621 & 0.830 \\
\hline \multirow[t]{2}{*}{ Mean Values } & 0.836 & 1.532 & 3.172 & 0.453 & 0.698 \\
\hline & & & & & $\begin{array}{l}\text { Above average } \\
\text { Below average }\end{array}$ \\
\hline
\end{tabular}
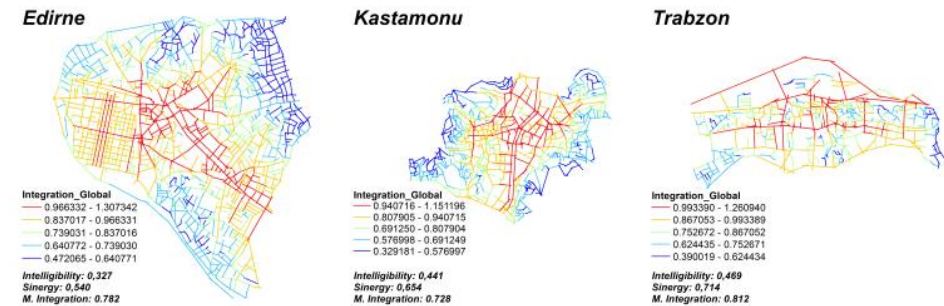

Figure 17. Integration maps of the selected cities' historical cores

Bursa

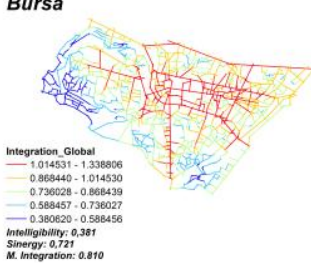

Kütahya

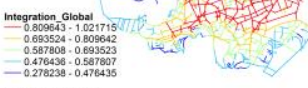

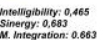

Muğla

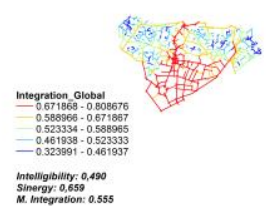

Sivas

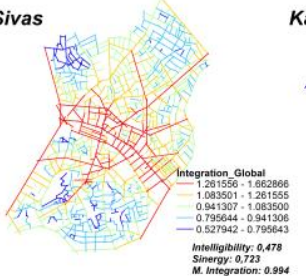

Kars
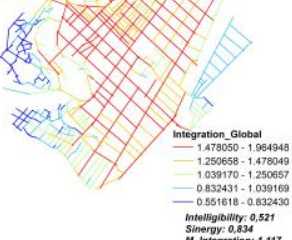

Kayseri

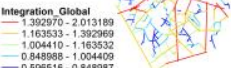

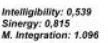

Tarsus

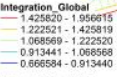

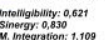

Erzurum

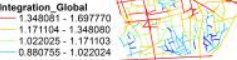

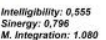

Urfa

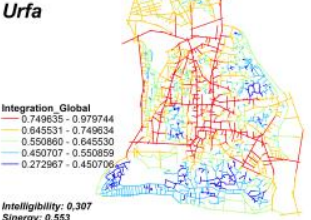

Mardin

Antakya

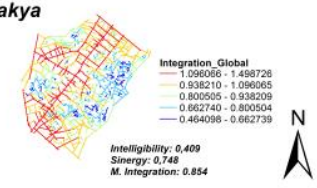




\section{CONCLUSION}

In this study, morphological structures of historical urban fabrics of settlements in Anatolia, which have been shaped up under the influence of various cultures and different geographic and climatic conditions through the historical process, are presented comparatively using a mathematical interpretation.

In the study, comparative, quantitative and morphological analyses were made on traditional urban patters of fourteen cities selected from the seven different geographical regions of Turkey, two from each of the regions. As a result of these analyses, detailed information was presented about the morphological structures of the urban forms on an urban scale as well as on a regional scale. In this context, the folowing conclusions have been reached within the framework of the specified methodological approach.

Table 5. Comparative morphological characteristics of the cities

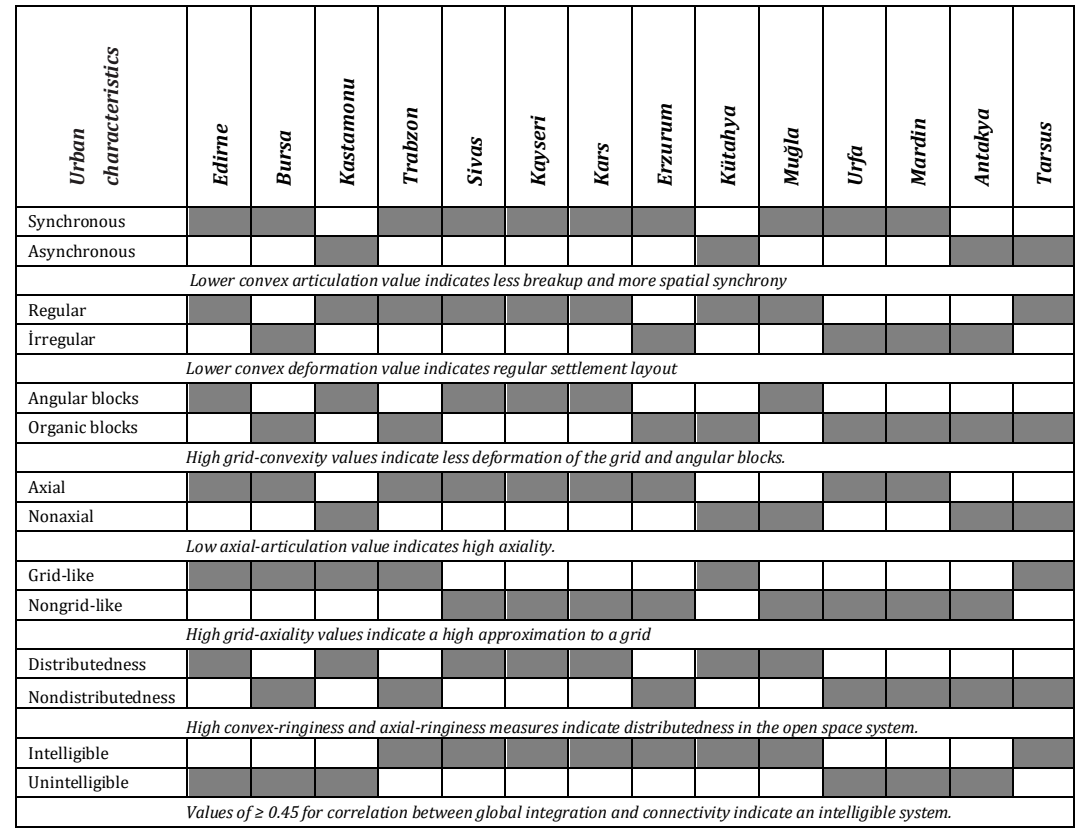

When an assessment is made in terms of synchrony of the fourteen cities, it is seen that ten have a more synchronous open space system. If we are to make a generalization based on this, we could say that the cities in Turkey have a synchronous structure. If we go into more detail, we could say that the cities selected from the Mediterranean Region are more asynchronous compared with the other cities. When an assessment is made in terms of regularity or irregularity, it is observed that nine of the fourteen cities reflect regular forms with values above the average. The remaining five cities, on the other hand, have more irregular forms than the other cities with values below the average. In conclusion, if we are to make a generalization, we could say that the cities in Turkey exhibit regular forms. When the degree of grid 
deformation is examined, it is observed that organic form is more predominant. Though eight cities exhibit below-the-average organic structure, a grid-like structure is too weak to be felt among the other cities with the exception of Edirne and Kars. When an assessment is made in terms of axiality, it is observed that nine of the fourteen historical urban cores selected for the sample have high levels of axiality. It should be stated that the cities chosen from the Aegean and Mediterranean Regions are among the other five historical urban cores that have lower axiality than the average. When the issue is examined in terms of distributedness, it could be stated that high values in the parameters of Convex Ringiness and Axial Ringiness indicate more grid-like structure than organic pattern in terms of the open space system.While it is possible to make an interpretation on an urban level, no data appeared that could allow for making a more generalized interpretation. High intelligibility values indicate that spatial configuration is more intelligible and easily predictable by users. It could be said at this point that Tarsus has the highest syntactic intelligibility value with 0.621 . When an interregional comparison is made in terms of the intelligibility parameter, it is seen that the cities in the Central Anatolia and Eastern Anatolia Regions have higher values, whereas the cities in the Marmara and SouthEastern Anatolia Regions have lower values (Table 5).

It could be stated that the results obtained from this study indicate that the analytical techniques offered by the Space Syntax method have made a significant contribution to the concretized formulation of spatial models and therefore could be designated as a means in demonstrating differences and resemblances of different built environments.

Anatolia, which is at a point where Asia and Europe meet, is a geography that has hosted many culture since the earliest civilizations of history were established. Anatolian cities, in particular, enjoy a historical legacy where spatial structures of Roman, Byzantine, Ottoman and Turkish cultures can be observed. In addition, the fact that geographically it enjoys different climatic conditions and topographic features seems to have a major influence on the spatial configuration of the cultures as well as on morphological formation of the geography. It is belived that a comparative analysis attempted in this study of the historical cores of the cities, which have been shaped up under the impact of rich historical and cultural heritage and geographical conditions, within the framework of a quantitative model will make a significant contribution to studies conducted on urban morphology, urban design, urban planning and architecture. 


\section{REFERENCES}

Aru, K. A. (1998). Türk Kenti [Turkish city].

Asami, Y., Kubat, A. S., \& Istek, C. (2001). Characterization of the street networks in the traditional Turkish urban form. Environment and Planning B: Planning and Design, 28(5), 777-795.

Bafna, S. (2003). Space syntax: A brief introduction to its logic and analytical techniques. Environment and Behavior, 35(1), 17-29.

Batty, M., \& Rana, S. (2002). Reformulating space syntax: the automatic definition and generation of axial lines and axial maps. Centre for Advanced Spatial Analysis Working Paper, 58.

Bölük, E. (2016). Köppen İklim Sinıflandırmasına Göre Türkiye Íklimi. Retrieved from Ankara:

Choudhary, P., \& Adane, V. (2012). Spatial configurations of the urban cores in central India. Paper presented at the Proc. 8 Int. Sp. syntax Symp. Santiago de Chile.

Conzen, M. R. G. (1960). Alnwick, Northumberland: a study in town-plan analysis. Transactions and Papers (Institute of British Geographers)(27), iii-122.

Cutini, V. (2001). Configuration and Centrality-Some evidence from two Italian case studies. Paper presented at the Space Syntax 3rd International Symposium Proceedings, 2001.

Demir, A. (1996). Through the Ages Antakya. İstanbul: İstanbul Akbank Culture and Art Publication.

Dursun, P. (2002). Trabzon kentsel dokusunda morfolojik analiz. Fen Bilimleri Enstitüsü,

Eskidemir, K. (2016). Kent Morfolojisi ve Kültür: Anadolu ve İtalya Kentleri Karşılaştırmalı Analizleri. Fen Bilimleri Enstitüsü, İstanbul Teknik Üniversitesi,

Fierro, M. I. (2011). The Western Islamic World, Eleventh to Eighteenth Centuries (Vol. 3). Cambridge: Cambridge University Press.

Hillier, B. (1989). The architecture of the urban object. Ekistics, 521.

Hillier, B. (1996). Space is the machine: a configurational theory of Architecture: Cambridge University Press.

Hillier, B. (1999). The hidden geometry of deformed grids: or, why space syntax works, when it looks as though it shouldn't. Environment and Planning B: Planning and Design, 26(2), 169-191.

Hillier, B., \& Hanson, J. (1984). The social logic of space, 1984. Cambridge: Press syndicate of the University of Cambridge.

Kaya, M. A. (2003). Anadolu'daki Roma Garnizonları. Tarih Incelemeleri Dergisi, 18(2), 83-94.

Kejanlı, T. (2005). Anadolu'da İlk Yerleşmeler ve Kentleşme Eğilimleri. Fırat Üniversitesi Doğu Araştırmaları Dergisi, 4(1), 89-97.

Kuban, D. (1968). Anadolu-Türk Şehri: Tarihî Gelişmesi, Sosyal ve Fizikî Özellikleri Üzerinde Bazı Gelişmeler. Vakıflar(3), 5373. 
Kubat, A. S. (1997). The morphological characteristics of Anatolian fortified towns. Environment and Planning B: Planning and Design, 24(1), 95-123.

Kubat, A. S. (1999). The morphological history of Istanbul. Urban Morphology, 3, 28-40.

Kubat, A. S. (2010). The study of urban form in Turkey. Urban Morphology, 14(1), 31-48.

Larkham, P. J. (2002). Misusing'morphology'?(Urban form). Urban Morphology, 6(2), 95-98.

Mohareb, N. I. (2009). Street morphology and its effect on pedestrian movement in historical Cairo. Cognitive processing, 10(2), 253-256.

Moudon, A. V. (1997). Urban morphology as an emerging interdisciplinary field. Urban Morphology, 1(1), 3-10.

Osmond, P. (2011). The convex space as the'atom'of urban analysis. The Journal of Space Syntax, 2(1), 97-114.

Özcan, K. (2006). Anadolu-Türk Kent Tarihinden Bir Kesit: Selçuklu Döneminde Anadolu-Türk Kent Modelleri. Bilig(38), 161-184.

Penn, A., Hillier, B., Banister, D., \& Xu, J. (1998). Configurational modelling of urban movement networks. Environment and Planning B: Planning and Design, 25(1), 59-84.

Peponis, J., Hadjinikolaou, E., Livieratos, C., \& Fatouros, D. A. (1989). The spatial core of urban culture. Ekistics, 43-55.

Tanyeli, U. (1987). Anadolu-Türk kentinde fiziksel yapının evrim süreci (11-15. yy). İstanbul Teknik Üniversitesi, Fen Bilimleri Enstitüsü, İstanbul.

Thilagam, N. L., \& Banerjee, U. K. (2016). The morphological characteristics of medieval temple towns of Tamilnadu. Environment and Planning B: planning and Design, 43(1), 7-33.

Tüter, R., \& Ökesli, D. S. (2015). Geleneksel Kent Merkezi Çeperinde Dönüşüm Tarsus Örneği. Paper presented at the Türkiye Kentsel Morfoloji Sempozyumu Temel Yaklaşımlar ve Teknikler, Mersin.

Varoudis, T. (2012). DepthmapX multi-platform spatial network analysis software. Version 0.30 OpenSource, http://varoudis.github.io/depthmapX.

Whitehand, J. (1986). Taking stock of urban geography. Area, 147151.

Yekbun, A. E., \& Çırak, A. A. (2018). Mardin Tarihi Kent Dokusunda Form Değişiminin Incelenmesi. Paper presented at the Türkiye Kentsel Morfoloji Araştırma Ağ II. Kentsel Morfoloji Sempozyumu "DeğişKent" Değișen Kent, Mekân ve Biçim", İstanbul.

\section{Resume}

Assoc. Prof. Dr. Mehmet Topçu received his B.Arch, MSc. \& PhD in Urban and Regional Planning from İstanbul Technical University, Faculty of Architecture. He is currently working as an Associate Professor at Konya Technical University. Major research interests include urban planning, urban economy, urban morphology, urban design, space syntax. 